\title{
MINI TINJAUAN PERANGKAT SUMBER DAYA MANUSIA (BRAINWARE) : ANALIS SISTEM
}

\author{
Selly Madela Br Ginting (0305202127)
}

Pendidikan Matematika, FITK Universitas Islam Negeri Sumatera Utara

\begin{abstract}
Abstrak
Di bidang IT, teknologi, dan khususnya di bidang komputer, kita tentunya telah mengetahui pekerjaan sseorang analis sistem. Analis sistem merupakan orang yang mengemban tanggungjawab untuk meneliti, merencanakan, mengoordinasikan, dan menyarankan pilihan sistem perangkat lunak dan sistem yang lebih cocok dengan keperluan bisnis atau perusahaan. Analis sistem memainkan peran yang amat diperlukan dalam metode mengembangkan suatu sistem. Seseorang yang merupakan seorang analis sistem dituntut memiliki minimal empat keahlian : analitis, teknis, manajerial, dan sosial (berkomunikasi dengan individu lain). Seorang analis sistem akan menjadi lebih mahir dalam melaksanakan pekerjaannya jika dia memiliki informasi bisnis dan proses yang intensif sehingga dia bahkan dapat bertindak sebagai perencana strategis, teknik bisnis sebaik tambahan sebagai konsultan teknologi data, dan berpeluang menggunakan teknologi. Tujuan penulisan artikel ini adalah untuk memperbanyak wawasan dan pengetahuan tentang profesi seorang analis sistem. Dalam artikel ini, metode penulisan yang digunakan oleh penulis adalah metode kualitatif.
\end{abstract}

Kata kunci : Komputer, Perangkat sumber daya manusia (brainware), Analis sistem 


\begin{abstract}
In the field of IT, technology, and especially in the field of computers, we certainly know the profession of a systems analyst. A systems analyst is someone who has the responsibility of researching, planning, coordinating and suggesting the choice of software systems and systems that best suit the needs of the business or company. Systems analysts play an indispensable role in systems development methods. A systems analyst must have at least four skills: analytical, technical, managerial, and social (communicating with others). A systems analyst will become more adept at doing his job if he or she has intensive business information and processes so that he or she can even act as a strategic planner, as well as additional business engineering as a data technology consultant, and have the opportunity to use technology. The purpose of writing this article is to increase insight and knowledge about the profession of a systems analyst. The writing method used by the author in this article is a qualitative method.
\end{abstract}

Keywords : Computer, Human resources device (brainware), System analyst

\title{
I. PENDAHULUAN
}

Untuk menghasilkan perangkat lunak yang bermutu, maka dalam proses pengembangannya harus melewati langkah-langkah, langkah awal yang harus dilakukan adalah mencari tahu karakter perangkat lunak, yaitu : software lebih cenderung sebagai hasil buatan logis atau suatu unsur fisik dari sistem. Oleh karena itu, metode mengembangkan perangkat lunak beda dari perangkat keras terlebih terhadapmembuat produk. Dan perangkat lunak berkembang atau bangun dari proses rekayasa atau disebut engineering, bukan hasil dari proses manufaktur dalam definisi buatan klasik. Kedua kegiatan ini bergantung terhadap adanya SDM, namun keterkaitan diantara SDM dengan penaikan daya guna dan kemangkusan pengembangan produk amat beda. Satu yang dapat dijadikan contohnya yaitu pada pengembangan hardware, apabila tenaga manusia ditambah, alhasil produksi akan melambung dengan bertahap-tahap. Namun tak berlaku 
dalam peningkatan jumlah tenaga manusia di dalam kegiatan pengembangan perangkat lunak.

Analis Sistem berperan amat kritis dalam kiat pengembangan sistem.

Kristanto mengemukakan Analis Sistem adalah insan yang memiliki kebisaan untuk melakukan analisis terhadap suatu sistem, memilih solusi untuk memecahkan problem dan menuntaskan masalah yang ada dengan memanfaatkan komputer. Maka, system analyst ini merupakan seorang individu yang dianggap sebagai kunci dalam proses pengembangan suatu sistem. Analis Sistem mendalami problem dan keperluan dari suatu perusahaan. Biasanya problem dan keperluan dari suatu perusahaan tersebut yaitu tentang bagaimana informasi, datta, komunikasi, manusia, dan teknologi informasii bias menaikkan capaian bisnis. Dalam proses penganalisaan dan pendesainan sistem informasi inilah yang dikerjakan oleh analis sistem, merekalah yang memiliki tanggung jawab terhadap hal itu.

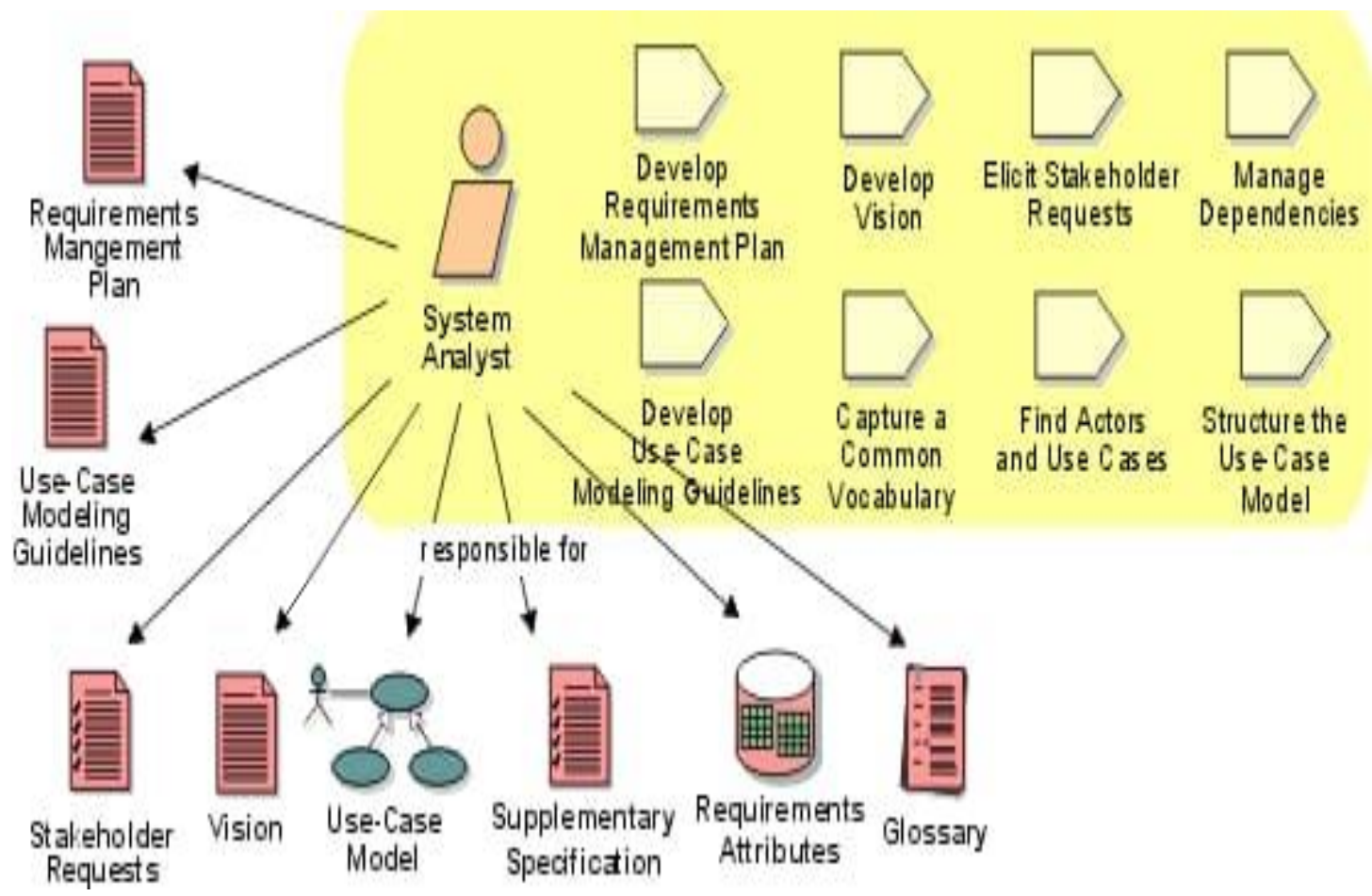


Jikalau tubuh seorang manusia tidak memiliki otak, tentunya organ dalam dan luar tubuh manusia tersebut tidak akan bekerja karena otak berperan sebagai pengontrol dan pendeteksi. Hal ini juga berlaku pada peran seorang analis sistem dalam suatu tim/organisasi. Seorang system analyst dianggap sebagai otak yang ada di dalam kepala pada kelompok proyek untuk mengembangkan perangkat lunak atau sistem informasi. Untuk memudahkan meningkatkan proses organisasional suatu perangkat lunak atau sistem informasi, analis sistem secara tersusun menganalisa bagaimana jalan kerja bisnis dengan cara memperhatikan proses peng-input-an dan pengolahan data serta proses peng-output-an informasi.

Salah satu pekerjaan yang cukup baik untuk memulai menjalankan karir dalam bidang IT adalah menjadi seorang analis sistem. Profesi sebagai analis sistem menyuguhkan rintangan kerja yang bervariasi dan dinamis. Analis sistem adalah seseorang yang menjadi kunci dalam proses pengembangan sistem. Karena analis sistem merupakan individu yang paling bertanggung jawab dalam proses analisis dan mendesain sistem informasi, maka tugas pokok dari seorang analis sistem adalah menentukan bentuk sistem yang akan dikembangkan nantinya. Dalam mengambil keputusan ini bukanlah mudah. Kekeliruan menetapkan konstruksi sistem yang akan dikembangkan akan berakibat pada gagalnya proyek yang sedang dikerjakan, oleh karena itu pekerjaan sebagai seorang analis sistem memiliki tanggungjawab yang besar.

\section{STUDI LITERATUR}

Dikutip dari bukunya yang berjudul "Perancangan Sistem Informasi Dan Aplikasinya", Kristanto mengemukakan Analis Sistem adalah individu yang memiliki kemampuan untuk melakukan analisis terhadap suatu sistem, memilih solusi untuk memecahkan problem dan menuntaskan masalah yang ada dengan memanfaatkan komputer. Maka, system analyst ini merupakan seorang individu yang dianggap sebagai kunci dalam proses pengembangan suatu sistem. Seorang analis sistem harus memiliki minimal empat keahlian : analitis, teknis, manajerial, dan sosial (berkomunikasi dengan orang lain). 
Sebuah sistem akan didesain oleh satu individu atau sekelompok individu yang membentuk suatu tim. Individu yang mendesain sistem tersebut dinamakan System Analyst.

Beberapa orang mendefinisikan analis sistem sebagai:

Seseorang yg memanfaatkan wawasan aplikasi computer yang ia punya guna dapat menuntaskan permasalahan-permasalahan yang ada dalam sebuah bisnis, dibawah arahan manajer sistem.

Seseorang yang memiliki tanggungjawab mengartikan keperluan-keperluan si pengguna sistem atau biasa disebut user ke dalam spessifikasi teknik yang dibutuhkan oleh programmer dan dipantau oleh manajemen.

System analyst adalah Sumber Daya Manusia (SDM) yang tugasnya mengumpulkan kasus-kasus proses bisnis yang akan diubah ke IT dan menampilkan dalam bahasa atau spesifikasi teknis yang mudah dipahami oleh programmer. Sehingga mereka mengetahui betul proses bisnis di lingkungan dan mempunyai pengetahuan IT. Tetapi nyatanya, profesi ini jarang yang berpengaruh karena tugasnya hanya musiman dan biasanya seorang programmer mampu melakukannya sendiri. Oleh sebab itu, fungsi system analyst biasanya dilakukan oleh salah satu seorang programmer.

\section{METODE PENELITIAN}

Artikel-artikel dan buku-buku yang sesuai dengan topik yang akan dibahas oleh penulis yaitu tentang analis sistem merupakan sumber data yang digunakan dalam penelitian ini. Dalam proses pengumpulan data, penulis mencari berbagai sumber data baik dari artikel maupun buku tentang profesi seorang analis sistem.

Setelah menemukan berbagai sumber data dari artikel dan buku yang sesuai dengan topik yang dibahas, selanjutnya penulis menganalisa dan memahami isi bacaan dari masing-masing artikel dan buku tersebut. Kemudian, penulis melakukan penyaringan data yang akan digunakan dalam menulis artikel tentang analis sistem ini. Setelah melakukan penyaringan, kemudian penulis 
membuat kriteria dari masing masing judul artikel dimana terdapat kata perangkat sumber daya manusia dan analis sistem.

Data-data yang diperoleh dari proses penyaringan selanjutnya dikembangkan menjadi tulisan tentang analis sistem. Penelitian ini dilakukan agar dapat membantu untuk lebih mengenal profesi seorang analis sistem. Diharapkan pemahaman tentang adanya penelitian ini dapat menambah wawasan dan manfaat yang positif bagi pembaca.

\section{PEMBAHASAN}

\section{A. Pengertian Analis Sistem}

Seseorang yang mengemban tanggung jawab untuk meneliti, merencanakan, mengoordinasikan, dan menyarankan pilihan sistem perangkat lunak dan sistem yang paling sesuai dengan keperluan bisnis atau perusahaan disebut sebagai analis sistem. Analis sistem memainkan peran yang amat diperlukan dalam metode pengembangan sistem. Salah satu pekerjaan yang cukup baik untuk memulai menjalankan karir dalam bidang IT adalah menjadi seorang analis sistem. Profesi sebagai analis sistem menyuguhkan rintangan kerja yang bervariasi dan dinamis. Analis sistem adalah seseorang yang menjadi kunci dalam proses pengembangan sistem. Karena analis sistem merupakan individu yang paling bertanggung jawab dalam proses analisis dan mendesain sistem informasi, maka tugas pokok dari seorang analis sistem adalah menentukan bentuk sistem yang akan dikembangkan nantinya. Dalam mengambil keputusan ini bukanlah mudah. Kekeliruan menetapkan konstruksi sistem yang akan dikembangkan akan berakibat pada gagalnya proyek yang sedang dikerjakan, oleh karena itu pekerjaan sebagai seorang analis sistem memiliki tanggungjawab yang besar.

Kristanto mengemukakan Analis Sistem adalah insan/individu yang memiliki kemampuan untuk melakukan analisis terhadap suatu sistem, memilih 
solusi untuk memecahkan problem dan menuntaskan problem yang ada dengan memanfaatkan komputer. Maka, system analyst ini merupakan seorang individu yang dianggap sebagai kunci dalam pengembangan suatu sistem. System analyst adalah Sumber Daya Manusia (SDM) yang tugasnya mengumpulkan kasus-kasus proses bisnis yang akan diubah ke IT dan menampilkan dalam bahasa atau spesifikasi teknis yang mudah dipahami oleh programmer.

\section{B. Keahlian Analis Sistem}

Untuk menjadi seorang analis sistem yang berkualitas dan sukses, analis sistem hendaknya mempunyai keahlian yang mumpuni, seperti :

1. Keahlian analisis

Keahlian analisis dibutuhkan untuk mengetahui organisasi yang membutuhkan sistem informasi yang akan dikembagkan. Untuk memetakan problematika yang dihadapi oleh perusahaan klien yang tidak dapat dituntaskan dengan system informasi dan yang bisa, dibutuhkanlah keahlian analisis ini. Selain itu, keahlian analisis pun dibutuhkan dalam menyelesaikan problem yang sudah diketahui lagi dengan memanfaatkan teknologi berbasis komputer. Keseluruhan kegiatan ini akan sangat tertolong dengan melihat organisasi sebagai sebuah sistem. Seorang analis sistem akan lebih gampang memahami keseluruhan proses bisnis yang berlangsung dan mengidentifikasi subsistem manakah yang mengalami masalah dengan melewati proses menganalisa unsur-unsurnya.

\section{Keahlian Teknis}

Tugas pokok seorang analis sistem adalah menentukan bentuk sistem ter-komputerisasi seperti apa yang bisa menuntaskan problem perusahaan(company) atau organisasi pengguna. Keahlian teknis yang diperlukan adalah penguasaan teknologi perangkat lunak (software) maupun perangkat keras (hardware) sebab permasalahan yang dijumpai hendaknya dituntaskan dengan teknologi komputer. Seorang analis system disyaratkan untuk mengenall dan menguasai software ataupun hardware 
terbaru, seta tahu kelebihan maupun batasan dari teknologi-taknologi tersebut. Hal ini akan amat memudahkan analis system dalam memilih teknologi yang sesuai untuk kebutuhan pengguna yang sangat detail. Melalui pendidikan formal, pelatihan khusus, ataupun jam terbang yang lama dalam membangun proyek sisteem informasi keahlian teknis ini dapat diperoleh.

3. Keahlian Manajerial

Salah satu tugas lainnya dari seorang analis sistem yaitu menjadi kepercayaan seorang manajerr sistem informasi dalam menyusun sumber daya proyek yang berspektrum kecil. Analis sistem mempunyai tanggung jawab menyusun cadangan yang berada dalam kontrolnya, seperti programer dan tekhnisi. Cepat ataupun lambatnya penyelesaian proyek dipengaruhi oleh pembangian tugas yang tepat. Analis sistem pun harus mampu meramal ancaman dan transformasi aspek-aspek eksternal seperti peningkatan harga hardware, transformasi keperluan klien, timbulnya produk rival, dan lain-lain.

4. Keahlian Sosial (berkomunikasi dengan individu lain)

Pihak yang berrkomunikasi aktif ke dalam dengan stakeholder yang lain ataupun keluar dengan klien adalah analis sistem. Untuk memfilter informasi yang tepat tentang problem yang ada pada klien, maka kemampuan berkomunikasi sangat dibutuhkan. Terkadang ada sebagian klien yang kurang terbuka atau kurang mengerti proses bisnis yang ia jalankan sendiri. Pada kesempatan kali inilah yang sangat menentukan kesuksesan identifikasi masalah adalah kemampuan berkomunikasi dari seorang analis sistem. Komunikasi pun dibutuhkan untuk menerangkan profesi dari analis sistem maupun stakeholder lain yang harus dipahami oleh pengguna. Serta komunikasi dibutuhkan untuk koordinasi dan arahan dengan stakeholder yang lainnya. Perkembangan proyek selalu dapat diketahui, transformasi-transformasi terkini bisa 
dikendalikan dan direspon dengan melakukan komunikasi yang benar dengan stakeholder yang lain.

\section{Tugas Analis Sistem}

Beberapa tugas yang dimiliki oleh seseorang yang berffrofesi sebagai analis sistem, yaitu sebagai berikut :

- Menghimpun dan menganalisis dokumen maupun file yang mempunyai kaitannya dengan sistem yang tengah berlangsung.

- Mengatur dan menyediakan laporan guna memperbaiki sistem yang sedang berjalan kepada pengguna.

- Medesain sebuah sistem perbaikan dan menandai aplikasi-aplikasi untuk penerapannya pada komputer.

- Menganalisis, menyusun tarif juga keuntungan yang diperoleh pada sistem yang baru.

- Mengawal berbagai kegiatan pada sistem yang baru dibuat.

\section{Perbedaan Analis Sistem dan Programmer}

Dalam penerapannya kedua jenis profesi ini bisa mencakup 2 tugas sekaligus yaitu apakah analis sistem yang mencakup sebagai programmer atau programmer yang mencakup sebagai analis sistem. Sehingga, terkadang dalam proses pengembangan sistem di antara analis sistem dan programmer sulit ditemukan perbedaannya.

Sistem analis adalah individu yang memiliki tugas untuk menganalisis sistem dengan mendalami problem-problem yang muncul dan menentukan keperluan-keperluan pengguna serta mengidentifikasikan solusi yang beralasan. Istilah lainnya yaitu : system designer, business analyst, system consultant, system engineer, software engineer, sistem analyst programmer, information system engineer. Sedangkan programmer merupakan individu yang bertugas untuk 
menulis kode program untuk sebuah aplikasi tertentu berlandaskan rancangan yang diciptakan oleh sistem analis.

\section{E. Langkah Kerja Dari Seorang Analis Sistem}

Seorang analis sistem dalam melakukan pekerjaannya perlu melewati langkah-langkah kerja. Adapun langkah-langkah kerja dari seorang Analis Sistem adalah sebagai berikut :

a. Tahap mengidentifikasi masalah yang terdapat di sebuah system.

b. Tahap mengerjakan studi kepatutan dan memahami performa dari system yang ada.

c. Tahap menganalisis dan pendesainan system.

d. Tahap melakukan penerapan system.

e. Tahap mengevaluasi dan pelestarian pada system.

\section{F. Etika Profesi Analis Sistem}

- Pada waktu menjalin interaksi dengan salah seorang pelanggan harus paham keperluan yang diperlukan oleh pelanggannya itu dengan berkomunikasi yang baik, tuntutan dari pelanggan harus sesuai dan terpenuhi. Untuk mewujudkan suatu perangkat lunak yang diinginkan, terlebih dahulu berinteraksi dengan desainer untuk berkomunikasi antarmuka. Agar dalam proses pengembangan sistem tetap pada porsinya, dibutuhkanlah interaksi ataupun menuntun seorang programmer.

- Mampu bekerjasama, supaya diantara kedua pihak yaitu analis sistem menjadi media perantara perusahaan penjual perangkat lunak(software) dengan organisasi tempat analis sistem tersebut bekerja bisa saling percaya harus diterapkan kejujuran.

- Tegas dalam mengambil keputusan, mengevaluasi sistem baik dengan ddata sampel atau data aslinya untuk menolong para penguji. Seorang 
analis sistem harus tegas dalam sebuah pengujian sistem supaya hasil yang didapatkan juga berkesan baik pula.

- Untuk menetapkan apakah sistem komputer tersebut laik untuk dipergunakan atau tidak, maka pada saat melakukan studi kepatutan system komputer harus mempunyai presisi yang tinggi. Dalam hal inilah seorang analis sistem dituntut untuk tepat dalam menjalankan proses analis system.

- Memikirkan sesuatu yang kreatif dalam memecahkan masalah, dengan membangun/menciptakan sistem yang baru dan lebih bagus dari sistem sebelumnya maka dapat menuntaskan masalah- masalah yang muncul.

\section{G. Kode Etik Analis Sistem}

Analis sistem memerlukan suatu kode etik. Suatu sistem norma, nilai \& juga aturan professional tertulis yang secara eksplisit mencantumkan apa yang tepat dan baik serta apa yang salah dan buruk bagi profesional disebut kode etik. Kode etik analis sistem sesungguhnya nyaris tak berbeda dengan kode etik yang ada pada programmer. Adapun kode etik seorang analis sistem adalah sebagai berikut :

1. Senantiasa mengikuti perkembangan ilmu computer

2. Tak diperbolehkan melakukan sesuatu yang memalukan bagi pekerjaannya sebagai seorang analis system.

3. Tak diperbolehkan membocorkan informasi-informasi vital karyawan dalam perusahaan.

4. Seorang analis sistem tak diperbolehkan dengan sengaja menciptakan system yang tidak tepat atau rumit untuk membingungkan.

5. Seorang analis sistem tak diperbolehkan memakai sistem dengan hak paten terkecuali telah membeli atau telah memohon izin dan sistem itu merupakan sistem yang sebelumnya telah ada. 
6. Tak diperbolehkan mencari laba tambahan dari proyek yang dbiayai oleh pihak kedua tanpa persetujuan.

7. Tak diperbolehkan menghakmiliki perangkat lunak khususnya alat pengembangan (development tools).

8. Tak diperbolehkan secara bersamaan kecuali dengan izin terlebih dahulu untuk memperoleh dana tambahan dari berbagai pihak eksternal dalam suatu proyek.

9. Tak diperbolehkan untuk mencari keuntungan dalam menaikkan status dengan cara menciptakan sistem yang dengan sengaja menumbangkan sistem lain.

10. Tak pernah merebut keuntungan dari pekerjaan individu lain.

\section{H. Peran Analis Sistem}

Dengan teratur menilai bagaimanakah fungsi bisnis denggan cara memperhatikan prosess masukan dan pengoIahan data serta proses keluaran informasi untuk menolong peningkatanproses organisasional, beginilah cara kerja seorang analis sistem. Dengan demikian, Analis Sistem memiliki 3 peranan penting :

a. Sebagai konsultan

Sebagai konsultan sistem untuk bisnis dan bisa dikontrak secara khusus untuk meninjau hal-hal yang berhubungan dengan sistem-sistem informasi di dalam sebuah bisnis biasanya merupakan peranan dari analis sistem. System analyst dengan bertahap-tahap bekerja sebagai konsultan untuk suatu perusahaan khususnya yang berhubungan terhadap penggolongan informasi organisasi. Hal ini bisa memunculkan surplus karena sistem analis adalah individu eksternal organisasi yang mempunyai sudut pandang yang lebih fresh dan lebih rasional atas proses pengolahan informasi di organisasi/perusahaan. Tapi kadang-kadang memungkinkan timbulnya rintangan yaitu terjadi ketidaksesuaian karena sistem analis 
tidak memahami kultur budaya yang terdapat di perusahaan.

b. Sebagai ahli pendukung pakar

Seorang analis sistem sebagai pendukung pakar mendukung pihak tata usaha dimana seorang sistem analis dipekerjakan, namun tidak memandu jalannya proyek. Untuk keperluan pengolahan informasi pada organisasi, maka analis sistem berperan sebagai perumus keperluan akan perangkat lunak (software) dan perangkat keras (hardware)

c. Sebagai agen perubahan

Ketika ia melakukan kegiatan sesuai pada siklus hidup pengembangan sistem, analis sistem kerap kali disebut sebagai agen perubahan. Agen perubahan bisa diartikan sebagai individu yang bekerja dengan fasilitas yang tersedia untuk perubahan dan memiliki peran sebagai katalis perubahan, mengembangkan dan menyiapkan perubahan. Tahap selanjutnya apabila perubahan tampak bermasalah sesudah proses analisis, yaitu menanggulangi segala akibat dari proses pengembangan sistem yang bermaslah atau menyimpang dengan mengembangkan sebuah skema perubahan.

\section{Tahapan Dalam Analisis Sistem}

Pekerjaan yang digeluti oleh seorang analis sistem adalah menganalisis system. Pengertian analisis system yaitu mengidentifikasi dan menguji bermacam-macam masalah maupun rintangan yang terjadi pada sistem sehingga kemudian dapat dilakukan perbaikan atau peningkatan dengan cara melakukan penjabaran sebuah sistem informasi yang sudah lengkap ke dalam bagian unsur-unsurnya. Seorang analis sistem dalam menganalisis sistem perlu melewati beberapa tahap. Berikut tahapan-tahapan dalam analisis sistem tersebut, yaitu :

a. Melakukan Identifikasi Masalah (Identify) 
Tahap pertama dari analisis sistem adalah Identifikasi masalah. Dalam tahap ini, dengan timbulnya pertanyaan yang ingin diselesaikan maka didefinisikanlah masalah yang harus diselesaikan.

b. Menguasai Kerja Sistem yang Ada (Understand)

Tahap ini dikerjakan dengan mendalami secara detail bagaimana berjalannya sistem yang telah ada. Dibutuhkan data yang bisa didapatkan dengan cara melakukan penyelidikan terhadap sistem untuk mendalami operasi dari sistem ini.

c. Menganalisis Sistem (Analyst)

Melakukan analisis hasil penelitian yang sudah dilakukan untuk mendapatkan solusi dalam memecahkan masalah yang ada dengan berpedoman pada data yang telah didapatkan.

d. Membuat Laporan (Report)

Agar terdapat bukti yang akurat secara tertulis tentang bagaimana hasil analisa yang sudah dikerjakan merupakan tujuan utama dari pembuatan laporan ini, maka pembuatan laporan sangat dibutuhkan. Pembuatan laporan diperlukan sebagai dokumentasi dari penelitian.

\section{J. OPSI (Organisasi Profesi System analyst Indonesia)}

Wadah perkumpulan sekelompok individu yang mepunyai visi dan misi bersama disebut organisasi. Kemudian mereka mewujudkan tujuannya dengan mengorganisasikan diri melalui cara bekerja bersama.

OPSI merupakan akronim dari Organisasi Profesi System analyst Indonesia. OPSI membebaskan untuk para analis sistem saling bertukar pendapat. Selain itu, dengan adanya organisasi ini para analis sistem bisa menciptakan sistem-sistem baru yang mungkin lebih baik dan bermutu dari sistem yang telah ada. Masyarakat dan para analis sistem bisa mencapai hasil yang sebelumnya belum dapat dicapai oleh seseorang secara sendiri-sendiri, ini merupakan keuntungan dari keberadaan OPSI. 
Adapun kode etik Sistem Analis pada OPSI (Organisasi Profesi System analyst Indonesia) adalah :

- Analis sistem Indonesia adalah warga negara Indonesia dan bertakwa kepada Tuhan YME

- Dalam menyalurkan pendapat, pemikiran dan pertimbangannya analis sistem Indonesia harus selalu memakai pendekatan yang demokratis, santun, dan tidak berburuk sangka

- Analis sistem Indonesia selalu menjaga kekompakan antar anggota organisasi, kepentingan organisasi lebih diutamakan daripada kepentingan pribadi anggota dan atau kelompok anggota

- Analis sistem Indonesia senantiasa menjaga nama baik organisasinya

- Analis sistem Indonesia dalam membagi pengalaman, memperluas pengetahuan, dan peningkatan pemahaman dalam bidang analis sistem harus selalu berusaha sungguh-sungguh

- Para analis sistem Indonesia harus menjauhi ketergantungan kepada pihak-pihak di luar organisasi secara langsung maupun tidak langsung dan menjunjung kemandirian 


\section{KESIMPULAN}

Analis Sistem adalah individu yang memiliki kemampuan untuk melakukan analisis terhadap suatu sistem, memilih solusi untuk memecahkan problem dan menuntaskan masalah yang ada dengan memanfaatkan komputer. Analis sistem memainkan peran yang amat diperlukan dalam metode pengembangan sistem. Empat keahlian seorang analis sistem : analitis, teknis, manajerial, dan sosial (berkomunikasi dengan individu lain). Setidaknya untuk menjadi seorang analis sistem, minimal harus menguasai keempat keahlian tersebut. Istilah lain dari analis sistem, yaitu : system designer, business analyst, system consultant, system engineer, software engineer, sistem analyst programmer, information system engineer.

Seorang analis sistem dalam menganalisis sistem perlu melewati beberapa tahap. Berikut tahapan-tahapan dalam analisis sistem tersebut, yaitu :
a. Melakukan Identifikasi Masalah (Identify)
b. Menguasai Kerja Sistem yang Ada (Understand)
c. Menganalisis Sistem (Analyst)
d. Membuat Laporan (Report)

Analis Sistem memiliki tiga peranan penting, yaitu :
a. Sebagai konsultan
b. Sebagai ahli pendukung pakar
c. Sebagai agen perubahan

OPSI merupakan akronim dari Organisasi Profesi System analyst Indonesia. OPSI membebaskan untuk para analis sistem saling bertukar pendapat. Selain itu, dengan adanya organisasi ini para analis sistem bisa menciptakan sistem-sistem baru yang mungkin lebih baik dan bermutu dari sistem yang telah ada. 


\section{DAFTAR PUSTAKA}

Yahfizham. 2019. Dasar-dasar Komputer. Medan : Perdana Pulishing.

Nurjaman, J. (2016). Peran Analis Sistem Dalam Pengembangan Perangkat Lunak. Jurnal Bangkit Indonesia, 5(1), 43.

Dennis, A., Wixom, B. H., dan Roth, R. M. 2013. System analysis \& design, 5th edition. John Wiley \& Sons.

Sugiyono. 2012. Memahami Penelitian Kualitatif. Bandung : CV. Alfabeta.

Al Fatta, Hanif. 2007. Analisis dan Perancangan Sistem Informasi untuk Keunggulan Bersaing Perusahaan dan Organisasi Modern. Yogyakarta : ANDI.

Kusrini, dan Andri Koniyo. 2007. Tuntunan Praktis Membangun Sistem Informasi Akuntansi dengan Visual Basic dan Microsoft SQL Server. Yogyakarta : ANDI.

Veermat, Shelly Cashman. 2007. Discovering Computers : Menjelajah Dunia Komputer Fundamental., Edisi 3. Jakarta : Salemba Infotek.

Albahra Bin Lajamuddin. 2005. Analisis Dan Sistem Informasi. Yogyakarta : Graha Ilmu.

Kristanto, Andri. 2003. Perancangan Sistem Informasi Dan Aplikasinya. Jakarta : Gava Media.

Jogiyanto, H.M . 2001. “Analisis Dan Desain Sistem Informasi : Pendekatan Terstruktur Teori Dan Aplikasi Bisnis 'Edisi Kedua' “, Andi Offset. Yogyakarta.

Gondodiyoto, Santoyo. 1998. Pengantar Komputer Dan Komputerisasi. Jakarta : Elek Media Komputido. 